\title{
Supreme Court To Chicago On Gun Control: Go To Heller!
}

\author{
Patrick J. Reville, B.B.A., J.D., Iona College, USA
}

\begin{abstract}
Gun Control. For or against, you are going to have a fight on your hands. But where is this fight to take place? Is it going to be on the village greens of Lexington and Concord? On the fields of Gettysburg? The dirt streets of Tombstone, leading on down to the O.K. Corral? Maybe at the base of the walls of the Alamo, down in San Antonio. Possibly on the campus of Kent State, or even at the now reserved setting of a school board meeting in Columbine. There are some mean streets in Ourtown, U.S.A. From New York City, to Washington D.C., and on to Chicago, where historic mob gun battles took place in the Capone Prohibition days, guns continue to blaze away. But what to do about it? Should we outlaw guns altogether? Or, as the saying goes, if we outlaw guns, will only outlaws have guns? Do we listen to Michael Moore, or the N.R.A.? Where can we find some common ground, and, maybe some answers? The United States Supreme Court has already heard oral arguments on the City Of Chicago's ban on handguns, and its decision is imminent. What will be the outcome, and where will the Court go to seek a majority, if not a consensus? The answer may be a not so long look back, to the Court's decision in District Of Columbia v. Heller (1), decided in June of 2008.
\end{abstract}

Keywords: Second Amendment, Gun Control, Heller.

\section{UNITED STATES CONSTITUTION AMENDMENT II}

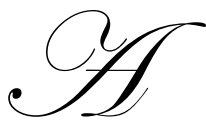

well regulated Militia, being necessary to the security of a free State, the right of the people to keep and bear arms, shall not be infringed. (2)

\section{HISTORIC BACKGROUND OF GUNS IN AMERICA}

As is pointed out by author Brian Doherty in his 2008 book Gun Control On Trial (3), many of America's legal underpinnings can be traced to English history. "A proximate ancestor of the Second Amendment is this clause from the English Declaration of Rights of 1689, stating that among the "true, ancient, and indubitable rights" secured by it was "that the Subjects which are Protestant may have Arms for their Defense suitable to their Condition, and as are allowed by Laws." (4) And in analyzing the writings of historian Joyce Malcolm, Doherty observes that "Even during times when Catholics were otherwise oppressed (out of fear that they intended to overthrow or subvert the Protestant kingdom), the Papists were still generally allowed to keep weapons sufficient for home defense." (5) It is clear that guns played a role in the lives of the early settlers, and, of course, during the revolutionary era. It is sometimes jokingly said that if the colonists did not have guns available to them in 1776, we would all be speaking better proper English now than we are (despite the fact that King George was of German descent). In the early years after ratification of the Second Amendment, many States' Constitutions included similar protections. While the first half of the $19^{\text {th }}$ century found many State court cases upholding the right to bear arms (6), the latter part would show a different leaning.

\section{PRIOR CASE LAW UNDER THE SECOND AMENDMENT}

The Fourteenth Amendment having been ratified in 1868, many thought that this provision would guarantee that the States would be brought into line as far as compliance with constitutional protections were 
concerned. Not necessarily so.

In United States v. Cruikshank (7), which was not actually a Second Amendment case, the seeds of doubt were strongly sewn as to whether the Fourteenth Amendment incorporated a requirement on the states to honor the Second Amendment. The claim was that the Second Amendment was a federal protection.

Presser v. Illinois (8) (which was a Second Amendment case) followed in 1886. A state statute barring public parades of armed parties without permission was held not a violation of the Second Amendment, in that the Second Amendment did not apply to the states.

The Supreme Court after Presser seemed generally uninterested in Second Amendment issues, except for the 1939 case of United States v. Miller. (9) Here, one Frank Layton transported a sawed-off shotgun across state lines, neglecting to pay a tax that was required by the newly enacted (1934) National Firearms Act. The statute did not outright ban certain weapons, but attempted to tax them out of existence and use (a strategy that was generally successful). When the case was argued, Doherty relates that the defendants' court-appointed counsel, lacking in meaningful funds, did not even file briefs, and did not travel to Washington, D.C., to orally argue the case. (10) The federal statute was held constitutional, and there was language in the bench announcement of the decision of Justice McReynolds that a sawed off shotgun had no relation to the militia. The seeds had been firmly planted for the position that the Second Amendment did not apply to an individual's rights, but to the rights of a militia, even though the case dealt with whether a sawed-off shotgun had a typical militia connection, not whether an individual had a right under the Second Amendment. (11)

Fast forward to 2001. The Fifth Circuit Court Of Appeals found that the Second Amendment did in fact encompass an individual's right under the Second Amendment. (12) Shortly after that decision, then U.S. Attorney General John Ashcroft re-affirmed his prior stated position that the Second Amendment rights applied to individuals in a memo to all U.S. attorneys. (13)

\section{DISTRICT OF COLUMBIA v. HELLER}

The Statute. At issue in the Heller case was a Washington D.C. Code that made it illegal to possess a handgun without registration, and you could not register one if you did not already one before the law was passed in 1976. The statute also made possession of long guns in your home illegal, unless unloaded and trigger-locked or disassembled. Penalties ranged from up to one (1) year in jail and/or a $\$ 1,000$ fine.

The Plaintiffs. The strategy was to cherry-pick a field of worthy plaintiffs that could survive typical jurisdictional pitfalls and personal prejudices. The decision was to go with six "qualified, sympathetic plaintiffs" as opposed to "some guy who carjacked somebody or just shot up a McDonald's". (14)

Shelly Parker, a black woman, was the original lead plaintiff. She was a former nurse, working in software design, who moved to a neighborhood in D.C. that was rampant with drug gangs. Trying to help "clean up the neighborhood" of the drug traffickers, she received numerous death threats. She was introduced to the legal team by Kenn Blanchard, who referred to himself on his website as: "Black Man With A Gun". He was a personal firearms instructor, trainer and speaker, and occasional NRA representative.

Tom Palmer was a senior editor at The Cato Institute. Palmer had years earlier been accosted by a gang of street toughs in California, and but for his possession and display of his handgun, might not have made it to the "gang of six" in the case.

George Lyon was a communications attorney with extensive experience in the use of weapons. The team of attorneys putting the case together found his expertise of great value.

Gillian St. Lawrence lived in Georgetown, and owned a long gun for protection. She felt that the restrictions of the D.C. law (unloaded, disassembled, trigger lock) rendered her weapon useless for protection. 
Tracey Hanson was a black woman who was an employee of the Department Of Agriculture. She did not have any particular "horror story" to tell; she just felt strongly about the Second Amendment issue.

Dick Anthony Heller, who became the lead plaintiff in the case when it went before the Supreme Court, ended up being the only member of the "gang of six" to have his case adjudicated, due to procedural and jurisdictional issues. If he had not been added to the team at the early stages of planning, the case likely would not have become the landmark that it has. Further, as Doherty notes: "The best hook about Heller for the press was his day job: a trained and licensed special police officer for the District. He even carried a gun in a federal office building where he'd sometimes see Supreme Court justices and staff...Yet, at the end of the day, he had to...turn in his gun and bullets and go home, defenseless." (15)

The Attorneys. Plaintiffs' legal team was made up of many contributors, but Robert Levy, Alan Gura and Clark Neily formed the nucleus.

The N.R.A. Involvement. Doherty's book (16) points out numerous instances wherein the National Rifle Association in fact was less than helpful, if not obstructionist, in its attempts at involvement in the Heller case. Suffice it to say, the NRA apparently had and has its own agenda, and its goals, objectives and its methods do not and did not necessarily make for a good fit with the goals of the plaintiffs and their team of attorneys.

The District Court Case. (Then lead) Plaintiff Shelly Parker sued in Federal District Court to block the enforcement of the D.C. statute. Her case was dismissed by that Court. (17)

The Court Of Appeals Case. The Circuit for the D.C. Circuit reversed. (18)

\section{The Supreme Court Case and Decision (19)}

The Supreme Court decided 5-4 in favor of (then sole remaining) plaintiff Dick Heller. Mr. Justice Scalia delivered the opinion of the Court, with Chief Justice Roberts and Justices Kennedy, Thomas and Alito concurring. Justices Stevens and Breyer filed dissenting opinions. The four Justices opposed joined in each of the dissenting opinions.

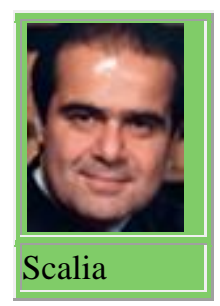

Decision: 5 votes for Heller, 4 votes against

Legal provision: Rights Of Individuals Under Second Amendment

Full Opinion by Justice Antonin Scalia

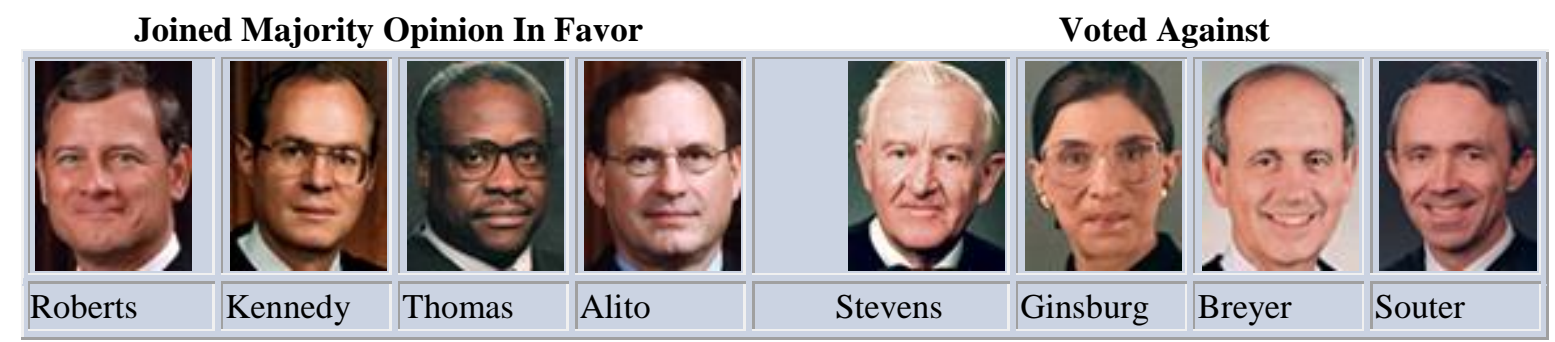

Source: The Oyez Project 


\section{Key Points Made By Justice Scalia.}

1. The Second Amendment protects an individual's right to possess a firearm unconnected with the service in a militia.

2. The Second Amendment right is not unlimited.

3. The (total) handgun ban and trigger-lock requirement violate the Second Amendment, as well as the requirement that any lawful firearm be disassembled or bound by a trigger lock making it impossible to use arms for their lawful purpose of self-defense.

\section{POST HELLER DEVELOPMENTS}

Initial Reaction. Understandably, the plaintiffs and counsel were elated, as were Second Amendment enthusiasts. The reaction from D.C. Police Chief Cathy L. Lanier and D.C. Mayor Adrian M. Fenty was quite the opposite. "When a federal appeals court ruled in March 2007, that the Second Amendment protects an individual's right to keep and bear arms, Mayor Fenty told reporters he was "outraged" by the decision." (20)

Heller Gets His Gun (Legally). Heller first attempt at registration after the case was decided was turned away in July after the case was decided. He thereafter returned the next day and began the registration process. On August 18, 2008, Dick Heller was issued his license to carry in D.C.

\section{The Chicago Case}

Attorney Alan Gura became the lead attorney in McDonald v. Chicago, challenging Chicago's handgun law. The issue is "whether the Second Amendment will be held to apply to localities, through incorporation via the Fourteenth Amendment." (21) The District Court has ruled against the plaintiffs (22); the Circuit Court Of Appeals has weighed in, affirming the District Court (23); the Supreme Court has heard oral argument (Winter, 2010); we await the Justices' decision as this article goes to print.

\section{CONCLUSIONS}

1. The topic of Gun Control is still alive and well in the minds of government executives, legislators, judges, prosecutors, attorneys and every-day citizens throughout the land.

2. Heller has been a breath of fresh air since 2008 for the proponents of the general citizenry's right to bear arms protections of the Second Amendment.

3. McDonald (pending) will presumably further clarify whether the interpretation in Heller will apply to the States (and, therefore, counties, cities, etc.).

4. The implementation of Heller (2008) and McDonald (2010) will take some time to filter down to Ourtown, U.S.A.

Editor's/Author's Note: On June 28, 2010, while this article was pending publication, the Supreme Court in fact decided in a 5-4 vote to sustain McDonald's position against the City Of Chicago's total ban on handguns. Mr. Justice Alito issued the opinion of the Court. The Court relied heavily on the principles set forth in Heller.

\section{AUTHOR INFORMATION}

Patrick J. Reville, B.B.A., J.D., earned his B.B.A. degree in Accounting from Iona College, New Rochelle, New York, in 1965, and the Juris Doctor degree from the Fordham University School Of Law in 1968. He Joined the Iona College faculty in 1975, and is presently an Professor of Business Law there. Attorney Reville has practiced law and accounting in Westchester County, New York, for over forty (40) years, and presently devotes his practice time to Criminal Law, Small Businesses, Real Estate and Estates. 


\section{FOOTNOTES}

1. $\quad 128$ S. Ct. 2783 (2008).

$2 . \quad$ U.S. CONST. amend. II.

3. Brian Doherty, Gun Control On Trial: Inside The Supreme Court Battle Over The Second Amendment (2008).

4. Id., at 2.

5. Id., at 3.

6. Id., at $12,13$.

7. 92 U.S. $542(1875)$.

8. $\quad 116$ U.S. $252(1886)$.

9. 307 U.S. 174 (1939).

10. Doherty, at 16-17.

11. Id.

12. United States v. Emerson, 203 F.3d 203 ( $5^{\text {th }}$ Cir. 2001).

13. Doherty, at 20.

14. Id., at 27.

15. Id., at 40.

16. Gun Control On Trial (2008).

17. Parker v. District of Columbia, 311 F. Supp. 2d 103 (D.C. 2004).

18. Parker v. District of Columbia, 478 F.3d 370 (D.C. Cir. 2007).

19. District Of Columbia v. Heller, 128 S.Ct. 2783 (2008).

20. Doherty, at 64-65.

21. Id., at 113.

22. McDonald v. Chicago, 2008 U.S.Dist. Lexis 98133.

23. NRA/McDonald v. Chicago, 567 F. 3d 856 ( $7^{\text {th }}$ Cir. 2009). 


\section{NOTES}

